\title{
Factores pronósticos en neoplasias malignas primarias de glándulas salivares. Estudio retrospectivo de 20 años*
}

\section{Prognostic factors in primary malignant salivary gland neoplasms. A 20 -year retrospective study}

\author{
A. Capote Moreno', L. Naval Gías², F.J. Rodríguez-Campo², M.F. Muñoz Guerra², \\ V. Escorial', F.J. Díaz González ${ }^{3}$
}

Resumen: Objetivo. Analizar los posibles factores pronósticos que pueden influir en la supervivencia y el desarrollo de recurrencias en nuestra serie de pacientes con neoplasias malignas primarias de glándulas salivares. Diseño del estudio. Se realiza un estudio retrospectivo de 75 pacientes con carcinomas glandulares tratados entre 1980 y el 2003. En todos los casos el tratamiento realizado ha sido la cirugía. Se administró radioterapia postoperatoria en un $52 \%$ de los pacientes. Se emplea el modelo de Kaplan-Meier para el análisis de supervivencia y el periodo libre de enfermedad. Así mismo, se analiza la posible asociación entre los diversos factores pronósticos y estas variables mediante el test Log Rank para el estudio univariante y el modelo de Cox para el multivariante. Resultado. La supervivencia global y causa-específica de la serie a 5 y 10 años ha sido del 74,9 y 63 y del 77,7 y 65,3\% respectivamente. El periodo libre de enfermedad ha sido de 51,8 y $43,2 \%$ a 5 y 10 años. De los factores analizados, la localización tumoral, el sexo, el estadio patológico, el tamaño tumoral, la parálisis facial, la infiltración perineural y la infiltración vascular han mostrado una influencia estadísticamente significativa en la supervivencia y/o recurrencias $(p<0,05)$, siendo factores independientes la parálisis facial y la infiltración vascular. Conclusiones. En la serie de pacientes presentada, los factores pronósticos más relevantes han sido la parálisis facial al diagnóstico y la infiltración vascular tumoral. La radioterapia postoperatoria complementaria no parece influir en la evolución de nuestros pacientes.

Palabras clave: Carcinoma de Glándula Salivar; Supervivencia; Periodo Libre de Enfermedad; Parálisis Facial.

Recibido: 15.11 .2004

Aceptado: 05.01.2005

\footnotetext{
1 Médico Residente.

2 Médico Adjunto.

3 Jefe de Servicio.

Servicio de Cirugía Oral y Maxilofacial. Hospital Universitario de La Princesa. Universidad Autónoma de Madrid. Madrid, España.

* Presentado como comunicación oral en el XVII Congreso Nacional de la Sociedad

Española de Cirugía Oral y Maxilofacial. Sevilla, Mayo 2003.
}

Correspondencia:

Dra. Ana Capote Moreno

C/ Valderribas 10, esc. drcha, 5으.

28007 Madrid, España.

e-mail: anacapote@inicia.es

\begin{abstract}
Objective. To analyze the possible prognostic factors for survival and disease-free survival in a group of patients with primary malignant salivary gland tumors. Design. Seventy-five patients with salivary gland carcinomas were studied retrospectively from 1980 to 2003. All cases were initially treated with surgery. Postoperative radiotherapy was applied in $52 \%$ of the patients. Survival and disease-free survival were analyzed with the Kaplan-Meier method. The association between the different prognostic factors and survival was studied with the Log Rank test for univariate analysis and the Cox proportional model for multivariate analysis. Results. The 5-year and 10-year crude survival rates were $74.9 \%$ and $63 \%$ and cause-specific survival rates were $77.7 \%$ and $65.3 \%$ respectively. The 5-year and 10-year disease-free survival rates were $51.8 \%$ and $43.2 \%$. Tumor location, sex, pathologic stage, tumor size, facial palsy, perineural spread and vascular spread showed statistical significance in survival and recurrence $(p<0.05)$. Facial palsy and vascular spread were prognostic factors in the multivariate analysis. Conclusion. In our group of patients, facial palsy and vascular spread are the most important factors for survival and recurrence. Postoperative radiotherapy does not appear to improve the prognosis of our patients.
\end{abstract}

Key words: Salivary Gland Carcinoma; Survival; Disease-Free Survival; Facial Palsy. 


\section{Introducción}

Las neoplasias malignas primarias de glándulas salivares constituyen un grupo heterogéneo de tumores con características histológicas diversas y variada respuesta a las distintas modalidades terapéuticas. Dichas neoplasias representan el 10-15\% de todos los tumores glandulares y el $1-3 \%$ de los tumores malignos de cabeza y cuello. ${ }^{1,2}$

La glándula parótida es la localización más frecuente donde asientan estos tumores, si bien el porcentaje relativo de malignidad es superior en los tumores de las glándulas salivares menores, mientras que en las glándulas mayores predominan las neoplasias de carácter benigno. ${ }^{3}$ En cuanto al pronóstico, el carcinoma de células claras y el carcinoma mucoepidermoide de bajo grado presentan mayores tasas de supervivencia que otras variedades histológicas como el adenocarcinoma, el carcinoma adenoide quístico o el carcinoma epidermoide..$^{4-6}$

La cirugía glandular sigue siendo hoy en día el tratamiento de elección para este tipo de neoplasias, avalado por estudios multicéntricos previos ${ }^{2}$ y por autores con amplia casuística. ${ }^{4}$ La radioterapia queda reservada como terapia adyuvante para aquellos pacientes con factores de mal pronóstico o como tratamiento paliativo en aquellos casos en los cuales se desestima la cirugía. No existe duda en cuanto a la indicación de disección cervical ante la presencia de adenopatías clínicamente positivas. Sin embargo, la disección electiva en el cáncer de glándulas salivares continúa siendo un tema controvertido. 4,7

Se han descrito diversos factores pronósticos asociados con la supervivencia de estas neoplasias así como con un mayor riesgo de desarrollar recurrencias locorregionales o metastasis a distancia. Factores como el tamaño tumoral, las metastasis cervicales el grado de malignidad o el tipo histológico son factores clásicos relacionados con el pronóstico de estos tumores.4,8-10 Así mismo, factores relacionados con el paciente como el sexo o la edad se han descrito como variables independientes en los estudios de supervivencia. ${ }^{8}$ Recientemente, se ha correlacionado la presencia de dolor y de parálisis facial al diagnóstico con un peor pronóstico en estas neoplasias. ${ }^{2,6}$

El objetivo del presente estudio han sido identificar los posibles factores pronósticos que pueden intervenir en la evolución de los pacientes de nuestra serie de tumores malignos primarios de glándulas salivares, analizando su relación con las tasas de supervivencia y con el desarrollo de recurrencias.

\section{Material y método}

Hemos realizado un estudio retrospectivo de 75 pacientes (41 varones y 34 mujeres; edad media de 59,17 años; rango de edad de 17 a 91 años), con tumores malignos primarios epiteliales de glándulas salivares que han sido tratados entre 1980 y el 2003 en el Servicio de Cirugía Oral y Maxilofacial del Hospital Universitario de La Princesa de Madrid. Se excluyen del análisis los melanomas, los linfomas, los sarcomas y las metástasis de carcinomas. El seguimiento de los pacientes se recoge de forma periódica en la base de

\section{Introduction}

Primary malignant salivary gland neoplasms make up a heterogeneous group of tumors with diverse histologic characteristics that have a varied response to different therapeutic models. These neoplasms represent $10-15 \%$ of all glandular tumors and $1-3 \%$ of malignant tumors of the head and neck. 1,2

These tumors are commonly located in the parotid gland, although the relative proportion of malignancy is superior in minor salivary gland tumors, while in the major salivary glands neoplasms of a benign nature predominate. ${ }^{3}$ With regard to prognosis, clear cell carcinoma and low-grade mucoepidermoid carcinoma have better survival rates than other histologic variants such as adenocarcinoma, cystic adenoid carcinoma or epidermoid carcinoma. . $^{4}$

Glandular surgery is still the treatment of choice for this type of neoplasm, and this has been backed by previous multicenter studies ${ }^{2}$ and by authors with an ample case experience. Radiotherapy is reserved as adjuvant therapy for those patients with bad prognosis factors, or as palliative treatment in those cases in which surgery is ruled out. There is no doubt as to the indication for neck dissection when there are clinically positive nodes. However, elective dissection in salivary gland cancer continues being a controversial issue. ${ }^{4,7}$

Various prognostic factors have been described that are related to the survival of these neoplasms as well as to a greater risk of developing locoregional recurrence or distant metastasis. Factors such as tumor size, cervical metastasis, the degree of malignancy or the histologic type are classic factors related with the prognosis of these tumors.,8-10 In this way, factors related with the patient such as sex and age have been described as independent variables in survival studies. ${ }^{8}$ Recent$l y$, the presence of pain and facial palsy at diagnosis has been correlated with a worse prognosis for these neoplasms.2,6

The objective of this study was to identify the possible prognosis factors that can affect the progression of patients in our series of primary malignant salivary gland tumors, by analyzing the relationship with survival rates and recurrence development.

\section{Material and methods}

A retrospective study was carried out of 75 patients (41 males and 34 females; mean age 59.17 years; age range 17 to 91 years), with primary malignant epithelial tumors of salivary glands treated between 1980 and 2003 by the Service of Oral and Maxillofacial surgery of the University Hospital of La Princesa, Madrid. The analysis of melanomas, lymphomas, sarcomas and carcinoma metastases was excluded. Patient follow-up was entered periodically into the tumor data base (MSDOS-dBASE) that exists in the Service. It was considered that the minimum follow-up period of the series should be 12 months (mean follow-up 56.93 months). 
datos de tumores (MSDOS-dBASE) existente en este Servicio. Se ha considerado un periodo de seguimiento mínimo de la serie de 12 meses (seguimiento medio de 56,93 meses).

El grupo de pacientes estudiado está constituido por 25 casos $(33,3 \%)$ con estadio I clínico, 5 casos $(6,7 \%)$ con estadio II, 34 casos $(45,3 \%)$ con estadio III, 10 casos $(13,3 \%)$ con estadio IV y un caso no estadiado por tratarse de un tumor oculto (Tx). El estadiaje de estos tumores, tanto clínico como patológico, se ha llevado a cabo según los criterios de la Clasificación TNM del American Joint Committee on Cancer. ${ }^{11}$

En el estudio preoperatorio se ha empleado la PAAF diagnóstica en 33 pacientes (44\%), mientras que se ha realizado una biopsia diagnóstica en 39 pacientes (52\%). La TC cervicofacial o la Resonancia Magnética han sido las pruebas de imagen empleadas para el estudio locorregional de extensión.

El tratamiento realizado en todos los casos ha sido la cirugía con resección local del tumor, asociada a disección cervical en 28 pacientes $(37,3 \%)$ por sospecha clínica o radiográfica de adenopatías cervicales positivas o de manera electiva al tratarse de neoplasias de alto grado de malignidad. La exéresis del tumor primario ha implicado la realización de ostectomía del hueso subyacente en 27 pacientes (36\%). En 1 caso se administró radioterapia preoperatoria para reducción del volumen tumoral.

Se emplea la radioterapia adyuvante postoperatoria en aquellos casos que cumplen los criterios establecidos en el Protocolo del Comité de Tumores del Hospital: dos o más adenopatías cervicales positivas, extensión ganglionar extracapsular, tumores de alto grado de malignidad o con extensión regional, afectación de los márgenes quirúrgicos de resección e infiltración tumoral perineural.

En el estudio estadístico de supervivencia global y causa-específica así como el periodo libre de enfermedad, se ha empleado el método de Kaplan-Meier. Así mismo, se han analizado los posibles factores pronósticos implicados en la evolución de estos tumores, utilizando el test Log Rank para el estudio univariante de supervivencia causa-específica y para el periodo libre de enfermedad. Los factores estudiados han sido: el sexo, la localización, la presencia de dolor y/o parálisis facial al diagnóstico, el tamaño tumoral (pT), el estadio tumoral (pTNM), el tipo histológico, los márgenes quirúrgicos, la infiltración perineural, la infiltración linfática y la infiltración vascular. Para identificar los factores independientes en el análisis multivariante, se emplea el modelo proporcional de Cox (hazard ratio). En todos los tests, el nivel de significación aceptado ha sido $p<0,05$. El estudio estadístico ha sido realizado mediante el programa SPSS 8.1.

\section{Resultados}

En la serie de pacientes estudiada, 34 casos $(45,3 \%)$ correspondieron con tumores localizados en la glándula parótida (uno de ellos de glándula accesoria), mientras que 33 casos (44\%) se han localizado en las glándulas salivares menores y 8 casos $(10,7 \%)$ en la glándula submaxilar. La histología de estos tumores ha mostrado una gran diversidad en el grupo global, siendo el carcinoma adenoide quístico la neoplasia de mayor frecuencia con 18
The group of patients that was studied was made up of 25 cases (33.3\%) with clinical stage I, 5 cases (6.7\%) with stage II, 34 cases (45.3\%) with stage III, 10 cases (13.3\%) with stage IV and one case that was not staged, as it was a hidden tumor (TX). The staging of these tumors, clinically as well as pathologically, was carried out according to the criteria of the TNM classification of the American Joint Committee on Cancer. ${ }^{11}$

In the preoperative study FNA diagnosis was used in 33 patients (44\%), while a diagnostic biopsy was carried out on 39 patients (52\%). The cervicofacial CAT scan or Magnetic Resonance were the diagnostic tests used for the study of locoregional extension.

The treatment carried out in all cases was surgical with local resection of the tumor combined with neck dissection in 28 patients (37.3\%) due to the clinical or radiographic suspicion of positive cervical adenopathy, or in an elective manner in neoplasms with high-grade malignancy. The removal of the primary tumor implied carrying out an osteotomy of the subjacent bone in 27 patients (36\%). In one case radiotherapy was administered preoperatively in order to reduce tumor volume.

Adjuvant postoperative radiotherapy was used in those cases meeting the established criteria of the Hospital's Tumor Protocol Committee: two or more positive cervical nodes, nodal extracapsular spread, tumors with high-grade malignancy or with regional extension, unclear surgical resection margins and perineural spread of the tumor.

In the statistical study of crude and cause-specific survival as well as of disease-free intervals, the Kaplan-Meier method was used. In this way, the possible prognostic factors implied in the progression of these tumors was analyzed, using the Log Rank test for the univariate study of causespecific survival and for disease-free intervals. The factors studied were: Sex, location, the presence of pain and/or facial palsy at diagnosis, tumor size (pT), tumor stage (pTNM), histologic type, surgical margins, perineural spread, lymphatic spread and vascular spread. In order to identify the independent factors in the multivariate analysis, the Cox proportional hazards model (hazard ratio) was used. In these tests, the accepted significance level was $p<0.05$. The statistical study was carried out using the SPSS 8.1 program.

\section{Results}

In the patient series studied, 34 cases (45.3\%) were related to tumors located in the parotid gland (one of them in an accessory gland), while in 33 cases (44\%) they were located in a minor salivary gland, and in 8 cases $(10.7 \%)$ in the submaxillary gland. The histology of these tumors has shown great diversity in the global group, with cystic adenoid carcinoma being the most common neoplasm in 18 patients (24\%), followed by adenocarcinoma in 11 patients (14.7\%) and low-grade mucoepidermoid carcinoma, high-grade 
pacientes (24\%), seguida del adenocarcinoma con 11 pacientes $(14,7 \%)$ y del carcinoma mucoepidermoide de bajo grado, el carcinoma mucoepidermoide de alto grado y el carcinoma epidermoide glandular con 7 pacientes respectivamente $(9,3 \%)$ (Tabla 1$)$. Sin embargo, el carcinoma adenoide quístico ha sido la neoplasia predominante en las glándulas menores ( 12 casos; $36,4 \%)$, mientras que el adenocarcinoma ha sido el tipo histológico más frecuente de las glándulas mayores (7 casos; 20,6\%).

La afectación del nervio facial en el momento del diagnóstico se ha objetivado en 11 pacientes $(14,7 \%)$, con parálisis de una o varias ramas del nervio o del tronco principal del mismo. Mientras tanto, 22 pacientes $(29,3 \%)$ presentaron dolor al diagnóstico.

Se ha empleado la radioterapia adyuvante postoperatoria en un $52 \%$ de los tumores (39 pacientes) según los criterios descritos previamente. De estos 39 pacientes, 31 casos $(79,5 \%)$ se correspondían con estadios avanzados de la enfermedad (estadios III y IV) y sólo 8 casos $(20,5 \%)$ con estadios precoces (estadios I y II).

En cuanto al tamaño anatomopatológico, se han identificado 16 pacientes $\mathrm{pT} 1,16$ pacientes $\mathrm{pT} 2,3$ pacientes pT3 y 40 pacientes pT4. De los 28 pacientes en los que se realizó disección cervical, 17 pacientes fueron por presentar metástasis ganglionares clínicamente positivas en el momento del diagnóstico. Sin embargo, un $26,7 \%$ de los casos (20 pacientes) han presentado una o varias adenopatías positivas en el estudio histológico definitivo por lo que en 3 pacientes se han identificado metástasis ganglionares ocultas (4\%). La distribución de la serie por estadios patológicos ha sido: 16 pacientes $(21,3 \%)$ con estadio I, 10 pacientes $(13,3 \%)$ con estadio II, 3 pacientes (4\%) con estadio III y 46 pacientes $(61,3 \%)$ con estadio IV.

Se han considerado márgenes quirúrgicos correctos aquellos libres de enfermedad tumoral y a una distancia mayor o igual a 5 $\mathrm{mm}$ de la misma. Por tanto, se han considerado unos márgenes correctos en la serie en 31 pacientes (41,3\%; 17 pacientes con estadios precoces y 14 pacientes con estadios tardíos), mientras que 44 pacientes (58,7\%; 10 pacientes con estadios precoces y 34 pacientes con estadios tardíos) han presentado afectación de los mismos. Se ha identificado la presencia de infiltración perineural por las células tumorales en 24 pacientes $(42,1 \%)$ de los 57 pacientes analiza- mucoepidermoid carcinoma and glandular epidermoid carcinoma in 7 patients respectively (9.3\%) (Table 1). However, cystic adenoid carcinoma was the predominant neoplasm in minor salivary glands (12 cases; $36.4 \%)$, while the adenocarcinoma was the most common histologic type in the major salivary glands (7 cases; 20.6\%).

Affected facial nerves were observed at diagnosis in 11 patients (14.7\%), together with paralysis in one or various branches of the nerve or of its main trunk, while 22 patients (29.3\%) had pain at diagnosis.

Postoperative adjuvant radiotherapy was used for $52 \%$ of tumors (39 patients) according to the criteria described previously. Of these 39 patients, 31 cases (79.5\%) were related to advanced stages of the disease (stages III and IV) and only 8 cases (20.5\%) were in the early stage (stages I and II).

With regard to anatomopathologic size, 16 patients were identified with $p T 1,16$ patients with $p T 2,3$ patients with pT3 and 40 patients with pT4. Of the 28 patients that underwent cervical dissection, 17 patients had nodal metastases that were clinically positive at diagnosis. However, in $26.7 \%$ of cases (20 patients) there was either one or various positive nodes in the definitive histologic study and, as a result, hidden nodal metastases was identified in three patients (4\%). The distribution in the series according to pathological staging was: 16 patients (21.3\%) with stage l, 10 patients (13.3\%) with stage II, 3 patients (4\%) with stage III and 46 patients (61.3\%) with stage IV.

The correct surgical margins were those that were tumor free and at a greater distance or equal to $5 \mathrm{~mm}$ from the tumor. Therefore in the series, 31 patients (41.3\%, 17 patients with early-stage and 14 patients with late-stage disease) were considered to have correct margins, while 44 patients (58.7\%; 10 patients with early-stage and 34 patients 
dos. Así mismo, 11 de 37 pacientes analizados $(29,7 \%)$ presentaron infiltración linfática y 3 de 39 pacientes analizados $(7,7 \%)$ infiltración vascular.

La supervivencia global de la serie, empleando el método de Kaplan-Meier, ha sido de un $74,9 \%$ a 5 años y un $63 \%$ a 10 años. La supervivencia causa-específica ha mostrado índices similares con un $77,7 \%$ a 5 años y un $65,3 \%$ a 10 años. Del total de posibles factores pronósticos estudiados en el análisis univariante, han mostrado una influencia estadísticamente significativa en la supervivencia de la serie la localización tumoral $(p=0,03)$, el estadio patológico $(p=0,006)$, la presencia de parálisis facial a diagnóstico $(p=0,02)$ (Fig. 1$)$, la infiltración perineural $(p=0,03)$ y la infiltración vascular $(p=0,001)$ (Fig. 2$)$. Otros factores como el sexo, el tamaño tumoral, la presencia de dolor al diagnóstico, los márgenes quirúrgicos, el tipo histológico o la infiltración linfática no han alcanzado el nivel de significación estadística. Analizando estas variables significativas mediante el modelo proporcional de Cox, la única que mostró una influencia estadísticamente significativa en el análisis multivariante de supervivencia ha sido la presencia de parálisis facial al diagnóstico (Tabla 2).

A lo largo del periodo de seguimiento, 32 pacientes $(43,8 \%)$ han presentado recurrencias de su enfermedad tumoral (Tabla 3) mientras que 41 pacientes $(56,2 \%)$ no han demostrado recidivas locorregionales ni a distancia. La tasa de recurrencias para tumores localizados en las glándulas mayores ha sido de un $53,7 \%$ (22 casos) frente a un $31,3 \%$ para las glándulas menores (10 casos). La tasa de supervivencia libre de enfermedad ha presentado valores de $51,8 \%$ a 5 años y de $43,2 \%$ a 10 años. En el análisis Log Rank del periodo libre de enfermedad, los factores estadísticamente significativos han sido: el sexo $(p=0,004)$, la localización tumoral $(p=0,04)$, el estadio patológico $(p=0,0001)$, el tamaño tumoral $(p=0,001)$, la Cox)

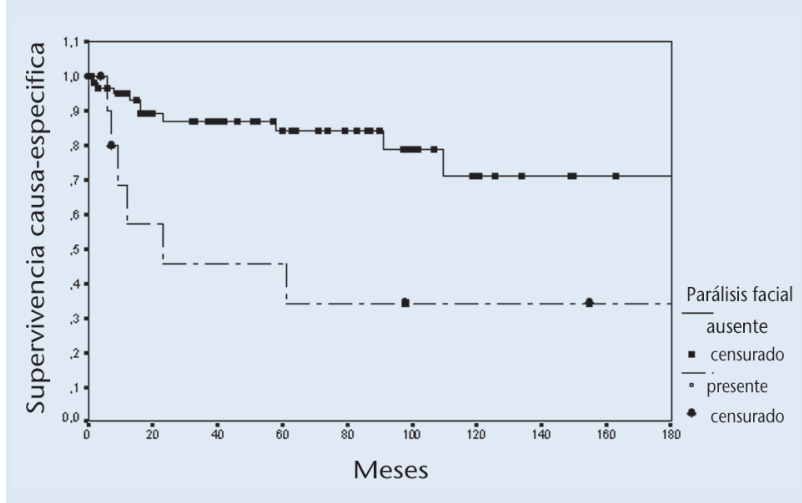

Figura 1. Curva de supervivencia causa-específica para la parálisis facial al diagnóstico $(p=0,02)$.

Figure 1. Cause-specific survival curve for facial palsy at diagnosis $(p=0.02)$.

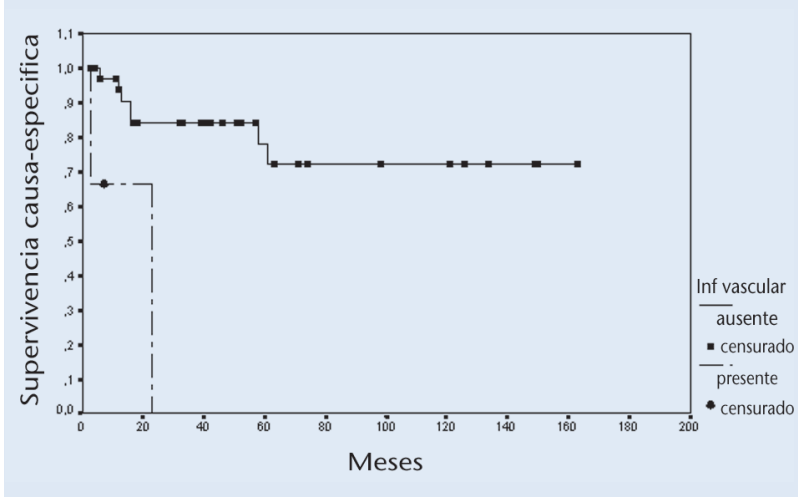

Figura 2. Curva de supervivencia causa-específica para la infiltración vascular tumoral $(p=0,001)$.

Figure 2. Cause-specific survival curve for vascular spread of tumor $(p=0.001)$.

Tabla 2. Análisis multivariante de supervivencia causa-específica (modelo de

$\begin{array}{lc} & \text { Supervivencia causa-específica } \\ \text { Significación }(p) & 0,82 \\ \text { Localización } & 0,001 \\ \text { Parálisis Facial* } & 0,12 \\ \text { Estadio patológico } & 0,42 \\ \text { Infiltración perineural } & 0,10 \\ \text { Infiltración vascular } & \\ \text { *Riesgo relativo: 3,29; IC 95\%, 1,59-6,83 } & \end{array}$

Table 2. Multivariate analysis of cause-specific survival (Cox model)

$\begin{array}{lc} & \text { Cause-specific survival } \\ & \text { Significance }(p) \\ \text { Location } & 0,82 \\ \text { Facial Palsy* } & 0,001 \\ \text { Pathologic Stage } & 0,12 \\ \text { Perineural Spread } & 0,42 \\ \text { Vascular Spread } & 0,10\end{array}$

${ }^{*}$ Relative risk: $3.29 ; \mathrm{Cl} 95 \%, 1.59-6.83$ with late-stage disease) had affected margins. Perineural spread by tumor cells in 24 patients (42.1\%) of the 57 patients analyzed was identified. Likewise, 11 out of the 37 patients analyzed (29.7\%) had lymphatic spread and 3 out of 39 patients analyzed (7.7\%) had vascular spread.

Crude survival in the series, using the Kaplan-Meier method, was $74.9 \%$ at five years and $63 \%$ at 10 years. Cause-specific survival showed similar rates with $77.7 \%$ at 5 years and $65.3 \%$ at 10 years. Of all the possible prognostic factors studied in the univariate analysis, the following had a statistically significant influence in survival rates of the series: tumor location $(p=0.03)$, pathological staging $(p=0.006)$, the presence of facial palsy at diagnosis $(p=0.02)$ (Fig. 1), perineural spread $(p=0.03)$ and vascular spread $(p=0.001$ ) (Fig. 2). Other factors such as sex, the size of the tumor, the presence of pain at diagnosis, surgical margins, histologic type or lymphatic spread did not reach a significant statistical level. On analyzing these significant variables using the Cox proportional model, the only variable that showed a statistically significant influence in the multivariate survival analysis was the presence of facial palsy at diagnosis (Table 2). During the follow-up period, 32 patients (43.8\%) suffered recurrence of tumor growth (Table 3) 
parálisis facial al diagnóstico $(p=0,04)$ (Fig. 3), y la infiltración vascular ( $p=0,0002)$ (Fig. 4). Así mismo, los factores que han resultado ser estadísticamente significativos en el análisis multivariante han sido la presencia de parálisis facial al diagnóstico y la infiltración vascular (Tabla 4).

En relación a los márgenes quirúrgicos, el grupo de pacientes con márgenes correctos ha mostrado una mejor evolución en cuanto a la supervivencia y el periodo libre de enfermedad, aunque estos resultados no han alcanzado una significación estadística $(p>0,05)$.

De los 48 pacientes diagnosticados como estadios avanzados, recibieron radioterapia postoperatoria 31 pacientes $(64,6 \%)$. Al analizar la influencia de la radioterapia en la evolución de estos pacientes mediante el test Log Rank de supervivencia y periodo libre de enfermedad, éste ha resultado ser un factor no significativo para ambos análisis estadísticos (supervivencia causa-específica: $p=0,2$; supervivencia libre de enfermedad: $p=0,3)$.

\section{Discusión}

Los carcinomas primarios de glándulas salivares se consideran neoplasias infrecuentes en el área de cabeza y cuello. Debido a esta baja frecuencia y a su gran diversidad histológica, existen pocos estudios que analicen globalmente los factores que intervienen en el comportamiento de estas neoplasias, centrándose la gran mayoría de ellos en las neoplasias que asientan sobre las glándulas mayores. ${ }^{2,4}$

La supervivencia global de la serie presentada ( $77,4 \%$ a 5 años) ha mostrado valores similares a los descritos por diversos autores (entre $81 \%-65 \%$ a 5 años). 2,6,12 Diversos estudios han tratado de analizar e identificar los posibles factores que se relacionan con el pronóstico de los pacientes y con un mayor riesgo de desarrollar recurrencias. Clásicamente se describe como variables significativas el tamaño tumoral (T), el estadio clínico (TNM)

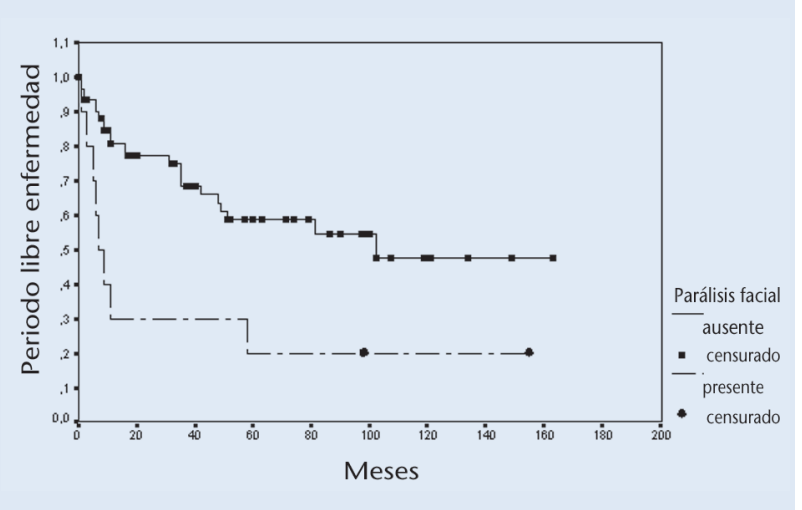

Figura 3. Curva de supervivencia libre de enfermedad para la parálisis facial al diagnóstico $(p=0,04)$.

Figure 3. Disease-free survival curve for facial palsy at diagnosis $(p=0.04)$.

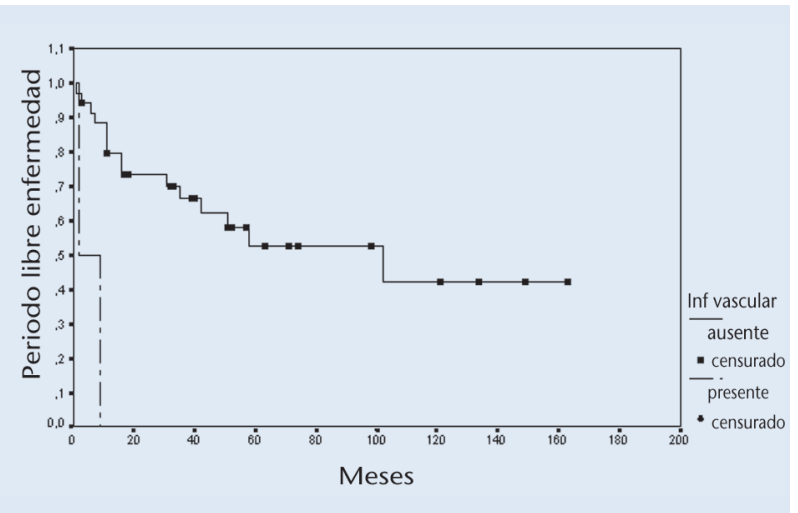

Figura 4. Curva de recurrencias para la infiltración vascular tumoral $(p=0,0002)$.

Figure 4. Recurrence curve for vascular spread of tumor $(p=0.0002)$. while 41 patients (56.2\%) did not suffer locoregional or distant recurrence. The recurrence rate for tumors located in the major glands was $53.7 \% \quad(22$ cases) as opposed to $31.3 \%$ for minor glands (10 cases). Disease free survival showed rates of $51.8 \%$ at 5 years and $43.2 \%$ at 10 years. In the $\log$ Rank analysis of the disease-free interval, the factors that were statistically significant were sex $(p=0.004)$, tumor location $(p=0.04)$, pathological stage $(p=0.0001)$, tumor size $(p=0.001)$, facial palsy at diagnosis ( $p=0.04)$ (Fig. 3), and vascular spread $(p=0.0002)$ (Fig. 4). Thus, the factors that turned out to be statistically significant in the multivariate analysis were facial palsy at diagnosis and vascular spread (Table 4).

With regard to surgical margins, the group of patients with correct margins showed better progression with regard to survival and disease-free intervals, although these results did not reach statistical significance $(p<0.05)$.

Of the 48 patients diagnosed with advanced stage tumors, 31 (64.6\%) received postoperative radiotherapy. On analyzing the influence of radiotherapy in patient progression by means of the Log Rank survival test and disease-free intervals, this turned out to be insignificant in both statistical analyses (cause-specific survival: $p=0.2$; diseasefree survival: $p=0.3$ ). 
y el tipo histológico.6,12-14 En nuestro análisis no hemos identificado una relación significativa entre estos factores y la supervivencia, mientras que el tamaño tumoral a resultado ser un factor relevante en relación con el periodo libre de enfermedad $(p=0,001)$. Para estudio estadístico hemos considerado el estadio patológico ya que el análisis histológico confirma tanto la extensión tumoral como el grado de afectación ganglionar. Este factor ha presentado significación estadística en los estudios univariantes, a pesar de no resultar un factor pronóstico independiente.

Para diversos autores como Therkildsen y cols., ${ }^{12} \mathrm{O}^{\prime}$ Brien y cols. ${ }^{15} \mathrm{O}$ Spiro y cols., ${ }^{16}$ la localización tumoral no parece influir en la supervivencia en los análisis multivariantes. Este hecho se confirma en nuestro estudio ya que, a pesar de resultar significativo en el test log rank, pierde dicho valor con el modelo de Cox.

La afectación del séptimo par craneal por las células neoplásicas previa al tratamiento quirúrgico, empeora significativamente el pronóstico de estos tumores. ${ }^{2,4-6}$ En este estudio se demuestra la influencia de la parálisis facial en la peor evolución de los pacientes, presentando una fuerte asociación tanto con la supervivencia como con las recurrencias. Otras característica clínica que se ha descrito en la literatura como un factor pronóstico negativo es la presencia de dolor preoperatorio; ${ }^{13}$ no obstante, este factor carece de significación estadística según los resultados obtenidos en el análisis descrito previamente.

Si bien se ha estudiado ampliamente sobre la infiltración perineural y la supervivencia, ${ }^{4,10}$ en pocos artículos se intenta correlacionar esta supervivencia con la presencia de infiltración linfática o vascular. En este análisis se ha demostrado una fuerte influencia de la infiltración vascular, incluso como un factor independiente que parece favorecer significativamente el desarrollo de recidivas. Este evento puede ser relevante para abrir nuevas vías de investigación y establecer alternativas terapéuticas en los tumores con afectación de los vasos sanguíneos intra y peritumorales.

Uno de los objetivos de la cirugía es conseguir unos márgenes quirúrgicos libres de afectación por las células tumorales, lo cuál ha sido considerado clásicamente como uno de los factores más relevantes para mejorar el pronóstico de los pacientes.2,5,9,12 En nuestro estudio, la presencia de unos márgenes quirúrgicos correctos sugiere una mejor evolución de ese grupo de pacientes, a pesar de que el resultado no ha mostrado una significación estadística en las curvas de supervivencia y periodo libre de enfermedad.

La existencia de adenopatías metastáticas al diagnóstico es una clara indicación de tratamiento quirúrgico del cuello con una disec-

\section{Discussion}

Primary carcinomas of the salivary glands are considered an uncommon neoplasm in the area of the head and neck. Due to this infrequency and to the considerable histologic diversity, there are very few global studies analyzing the factors that intervene in the behavior of these neoplasms, as most of these concentrate on neoplasms of the major salivary glands. ${ }^{2,4}$

Crude survival in the series presented ( $77.4 \%$ at 5 years) has shown similar values to those described by various authors (between $81 \%$ $65 \%$ at five years), 2,6,12 Various studies have tried to analyze and identify the possible factors related to the prognosis of these patients that carry a greater risk of recurrence. Classically, significant variables include tumor size $(T)$, clinical stage (TNM) and histologic type.6,12-14 In our analysis we have not identified a significant relationship between these factors and survival, while the size of the tumor was a relevant factor in relation with disease-free intervals $(p=0.0001)$. For statistical study purposes the pathological stage was taken into account, as the histologic analysis confirmed the extension of the tumor as well as the degree of lymph node involvement. This factor has had statistical significance in univariate studies, despite not turning out to be an independent prognostic factor.

For various authors such as Therkildsen et al, ${ }^{12}$ O'Brien et al ${ }^{15}$ or Spiro el al, ${ }^{16}$ tumor location does not seem to influence survival in multivariate analyses. This fact is confirmed in our study as, in spite of being significant in the log rank test, it looses value in the Cox model.

Neoplastic cell involvement of the seventh pair of cranial nerves before surgical treatment significantly worsens the prognosis for these tumors. 2,4-6 In this study the influence of facial palsy in a worse patient prognosis was demonstrated, together with a strong association with survival as well as recurrence. Another clinical characteristic described in the literature with a negative prognostic factor is the presence of preoperative pain. ${ }^{13}$ Nevertheless, this factor does not have 
ción cervical reglada. Sin embargo, continúa siendo un tema de controversia la indicación de un tratamiento electivo del cuello.1,17 Mientras que en la serie de estudio se ha identificado una incidencia global de metástasis ganglionares del $26,7 \%$, tasa de metástasis ocultas ha sido de un $4 \%$, la tasa relativamente baja respecto a otros autores.4,17 Según Amstrong y cols., 17 el riesgo de metastasis ganglionares ocultas en tumores de glándulas salivares mayores se asocia con el tamaño tumoral y con el grado histológico. Por ello, en determinados casos con factores de riesgo asociados, se debe llevar a cabo una cirugía electiva del cuello. Los criterios que determinan esta indicación varían de unos autores a otros según los resultados obtenidos en sus estudios. En general, se recomienda la realización de una disección cervical electiva en aquellos tumores con alto grado de malignidad y en tumores localmente agresivos con extensión regional. ${ }^{12,17}$

La radioterapia postoperatoria asociada al tratamiento quirúrgico del tumor primario, ha mostrado una influencia significativa en la evolución de estos pacientes.7,12,17-21 Esto se ha observado principalmente en la mejoría de las tasas de control locorregional tras el tratamiento radioterápico. ${ }^{2,19-21} \mathrm{~A}$ pesar de no contar con unos criterios universales sobre las indicaciones de radioterapia en las neoplasias de glándulas salivares, si existe una cierta concordancia entre los diversos autores en cuanto a qué casos serían susceptibles de recibir este tratamiento. La presencia de adenopatías patológicas, los tumores de alto grado de malignidad o con estadios avanzados (III y IV), los tumores localmente agresivos (T3 y T4), la afectación de los márgenes quirúrgicos, o la infiltración perineural, son los principales criterios que determinan la necesidad de irradiación complementaria tanto del lecho quirúrgico como del cuello afecto. ${ }^{2,10,13,18}$ No obstante, en la serie presentada no se ha demostrado un efecto beneficioso de la radioterapia postoperatoria tanto en el control de las recidivas como en la mejoría de la supervivencia. Esto podría deberse tanto a cambios a lo largo del tiempo en los criterios de selección de los pacientes que deben recibir este tratamiento como a la ausencia de grupos con características similares que permitan comparar las distintas modalidades terapéuticas.

\section{Conclusiones}

Como conclusión, se puede afirmar que las neoplasias malignas de glándulas salivares forman un grupo heterogéneo de tumores con características y comportamientos diversos que dificulta la realización de estudios de supervivencia y la identificación de los diferentes factores de riesgo. La localización tumoral, el sexo, el estadio patológico, la presencia de parálisis facial al diagnóstico, la infiltración perineural y la infiltración vascular han resultado ser factores pronósticos de supervivencia y/o de recurrencias en el análisis univariante del presente estudio, siendo factores independientes la parálisis facial y la infiltración vascular. La radioterapia complementaria no parece mejorar la supervivencia de los pacientes en la serie presentada, no encontrándose diferencias significativas entre este tratamiento y el tratamiento quirúrgico aislado. statistical significance according to the results obtained in the analysis we have described.

Although perineural spread and survival has been widely studied, ${ }^{4,10}$ in very few articles has there been an attempt at correlating survival with the presence of lymphatic or vascular spread. In this analysis the strong influence of vascular spread was demonstrated, even as an independent factor, as it appears to favor an increase in recurrence significantly. This fact could be relevant for opening new lines of investigation and for establishing therapeutic alternatives for tumors with intra and peritumoral blood vessel involvement.

One of the objectives of surgery is to achieve tumor cellfree margins, which has classically been considered to be one of the most relevant factors for improving patient prognosis. 2,5,9,12 In our study, the presence of correct surgical margins is suggestive of a better prognosis for these patients, despite the result not showing a statistical significance in survival curves and disease-free intervals.

The existence of nodal metastasis at diagnosis is a clear indication for surgical treatment of the neck with routine neck dissection. However, the indications for elective neck treatment continue being a controversial issue. 1,17 While in the study series, a crude incidence of nodal metastases was identified of $26.7 \%$, the hidden metastasis rate was $4 \%$, a relatively low rate with regard to other authors. 4,17 According to Armstrong et al, ${ }^{17}$ the risk of hidden nodal metastasis in major salivary gland tumors is associated with the size of the tumor and with the histologic grade. Therefore, in certain cases with associated risk factors, elective surgery of the neck should be carried out. The criteria determining this indication vary from one author to the other according to the results obtained in the studies. In general, carrying out elective neck dissection is recommended for tumors with a high degree of malignancy and for locally aggressive tumors with regional extension. ${ }^{12,17}$

Postoperative radiotherapy in conjunction with surgical treatment for primary tumors has been demonstrated as significantly influencing the progression of these patients. 7,12,17. 21 This has been observed principally in improvements in the rates of locoregional control following radiotherapy. 2,19-21 In spite of there not being universal criteria as to the indications of radiotherapy for salivary gland neoplasms, there is a certain concordance among various authors as to what cases are eligible for treatment. The existence of pathologic adenopathy, tumors with a high degree of malignancy or in advanced stages (III and IV), locally aggressive tumors (T3 and T4), affected surgical margins, perineural spread form the principal criteria that determine the need for complementary irradiation of the surgical bed and the affected neck. 2, 10,13,18 Nevertheless, in the series presented the beneficial effect of postoperative radiotherapy has not been demonstrated with regard to recurrence control and survival improvement. This could be due to changes over time in the selection criteria used for the patients that are eligible for 


\section{Bibliografía}

1. Bhattacharyya N, Fried MP. Nodal metastasis in major salivary gland cancer. Predictive factors and effects on survival. Arch Otolaryngol Head Neck Surg 2002;128:904-8.

2. Tullio A, Marchetti C, Sesenna E, Brusati R, Cocchi R, Eusebi V. Treatment of carcinoma of the parotid gland: results of a multicenter study. J Oral Maxillofac Surg 2001;59:263-70.

3. Rinaldo A, Shaha AR, Pellitteri PK, Bradley PJ, Ferlito A. Management of malignant sublingual salivary gland tumors. Oral Oncology 2004;40:2-5.

4. Régis de Brito Santos I, Kowalski LP, Cavalcante de Araujo V, Flávia Logullo A. Multivariate analysis of risk factors for neck metastases in surgically treated parotid carcinomas. Arch Otolaryngol Head Neck Surg 2001;127:56-60.

5. Bhattacharyya N. Survival and prognosis for cancer of the submandibular gland. J Oral Maxillofac Surg 2004;62:427-30.

6. Carinci F, Farina A, Pelucchi S, y cols. Parotid gland carcinoma:1987 and 1997 UICC T classifications compared for prognostic accuracy at 5 years. Eur Arch Otorhinolaryngol 2001;258:150-4.

7. Lee $S$, Kim GE, Park CS, y cols. Primary squamous cell carcinoma of the parotid gland. Am / Otolaryngol 2001;22:400-6.

8. Wahlberg P, Anderson H, Biörklund A, Möller T, Perfekt R. Carcinoma of the parotid and submandibular glandsæa study of survival in 2465 patients. Oral Oncol 2002;38:706-13.

9. Brandwein M, Ivanov K, Wallace DI y cols. Mucoepidermoid carcinoma. A clinicopathologic study of 80 patients with special reference to histologycal grading. Am J Surg Pathol 2001;25:835-45.

10. Kokemueller H, Eckardt A, Brachvogel P, Hausamen JE. Adenoid cystic carcinoma of the head and necka 20 years experience. Int J Oral Maxillofac Surg 2004;33:25-31.

11. Greene FL, Page D, Morrow M, y cols. (eds.) A/CC Cancer Staging Manual, 6th ed. New York: Springer, 2002.

12. Therkildsen MH, Christensen M, Andersen LJ, y cols: Salivary gland carcinomasprognostic factors. Acta Oncol 1998;37:701-12.

13. Camilleri IG, Malata CM, McLean NR, Kelly CG. Malignant tumors of the submandibular salivary gland: a 15-year review. Br J Plast Surg 1998;51:181-5.

14. Spiro RH. Salivary neoplasms: overview of a 35-year experiencewith 2807 . Head Neck Surg 1986;8:177-84.

15. O’Brien CJ, Soong S, Herrera GA, Urist MM, Maddox WA. Malignant salivary tumors-analysis of prognostic factors and survival. Head Neck Surg 1986;6:8292.

16. Spiro RH, Thaler HT, Hicks WF, Kher Ua, Huvos AH, Strong EW. The importance of clinical staging of minor salivary gland carcinomas. Am / Surg 1991;162:3306.

17. Armstrong JG, Harrison LB, Thaler HT, y cols. The indications for elective treatment of the neck in cancer of the major salivary glands. Cancer 1992;69:615-9.

18. Harrison LB, Armstrong JG, Spiro RH, Fass DE, Strong E. Postoperative radiation therapy for major salivary gland malignancies. J Surg Oncol 1990;45:52-5.

19. Armstrong JG, Harrison LB, Spiro RH, Fass DE, Strong EW, Fuks ZY. Malignant tumors of major salivary gland origin: a matched pair analysis of the role of combined surgery and postoperative radiation therapy. Arch Otolaryngol Head Neck Surg 1990;116:290-3.

20. North CA, Lee DJ, Piandosi S, Zahurak M, Johns ME. Carcinoma of the major salivary glands treated by surgery or surgery plus postoperative radiotherapy. Int J Radiat Oncol Biol Phys 1990;18:1319-23.

21. Borthne A, Kjellevold K, Kaalhus O, Vermund H. Salivary gland malignant neoplasms: treatment and prognosis. Int J Radiat Oncol Biol Phys 1986;12:747-54. this treatment, as well as to the absence of groups with similar characteristics that would have allowed comparisons of the different therapeutic modalities.

\section{Discussion}

In conclusion, it can be affirmed that malignant neoplasms of salivary glands form a heterogeneous group of tumors with diverse characteristics and behavior that makes carrying out survival studies and identifying the different risk factors difficult. Tumor location, sex, pathologic stage, the presence of facial palsy at diagnosis, perineural and vascular spread have turned out to be prognostic factors for survival and/or recurrence in the univariate analysis of this study, with facial palsy and vascular spread being independent factors. Complementary radiotherapy does not appear to improve survival in patients in the series presented, and no significant differences were found between this treatment and isolated surgical treatment. 